\title{
Distribution of Glycocholate in Blood from Human Fetuses and Adults
}

\author{
RICHARD C. STRANGE, ${ }^{(24)}$ ROBERT HUME, DAVID W. EADINGTON, AND IAN A. NIMMO \\ Department of Clinical Chemistry, University of Edinburgh, Royal Infirmary, Edinburgh, EH3 $9 Y W$, Scotland, \\ United Kingdom [R. C. S., D. W. E.]; Department of Child Life and Health, Hatton Place, Edinburgh, EH9 IUD, \\ Scotland, United Kingdom [R. H.]; Department of Biochemistry, University of Edinburgh Medical School, Hugh \\ Robson Building, George Square, EH8 9XD, Scotland, United Kingdom [I. A. N.]
}

\begin{abstract}
Summary
Glycocholate binding by plasma proteins and erythrocytes from fetal and adult blood has been studied, and the results have been used to derive a compartmental model of the distribution of glycocholate in blood. This model assumes that glycocholate is distributed between the aqueous phase, albumin binding sites, binding sites on other plasma proteins, and erythrocytes. Whereas glycocholate binding by albumin was saturable [fetal blood: dissociation constant $(0.5 \mathrm{mM})$, concentration of binding sites (11.3 $\mu$ moles/g protein); adult blood: dissociation constant $(0.42 \mathrm{mM})$, concentration of binding sites ( $20.1 \mu$ moles/g protein)], binding by other plasma proteins was not. The association of glycocholate with erythrocytes appeared to be based on partitioning rather than binding of the bile salt to specific sites. The value of the partition coefficient was 6.0. The compartmental model indicates that, in fetal blood, $46 \%$ of the glycocholate is in free solution, and $37 \%$ is bound to albumin. In blood from adults, the corresponding values are $31 \%$ in free solution and $59 \%$ bound to albumin.
\end{abstract}

\section{Speculation}

The studies described indicate that in the human fetus, although the concentration in blood of conjugated cholate is similar to the concentration in adults, the distribution of glycocholate is different. In particular, the concentration of free-diffusible bile salt is greater in fetal than in adult blood. Inasmuch as the concentration difference results in a bile salt gradient between fetal and maternal blood, it may be responsible for the observed passage of fetal bile salt into the maternal circulation.

Studies in several species have demonstrated an enterohepatic circulation of bile salts in fetal animals (6). In primates, it appears that there is also transport of bile salts across the placenta; for example, when $\left[{ }^{14} \mathrm{C}\right]$ cholate is infused into fetal monkeys, about $30 \%$ of the infused bile salt appears in maternal bile $(6,7,15)$.

The mechanism of bile salt uptake by the placenta will depend partly on the distribution of bile salts in fetal blood. This distribution is difficult to determine directly because in blood bile salts can associate with plasma proteins and erythrocytes. For example, bile salts are bound by plasma proteins, in particular by albumin $(3,11)$. In the studies described below, a compartmental model has been derived that allows the distribution of glycocholate in fetal blood to be calculated. The model is based on the isotherm characterising the binding of bile salts to proteins and on the partition coefficient for the association of bile salt with erythrocytes.

Whereas binding of bile salts by serum from human adults has been described $(3,11)$, similar studies have not been reported in the fetus. The binding of bile salts by plasma from adults and fetuses would be expected to be different, firstly, because several studies have shown reduced binding of drugs by fetal plasma compared to plasma from adults $(5,8)$ and secondly, because hypoalbuminaemia is frequently found in newborn humans. We now describe the binding of the glycine conjugate of cholic acid $(3 \alpha, 7 \alpha, 12 \alpha$-trihydroxy-5 $\beta$-cholan-24-oic acid) by human fetal plasma, erythrocytes, and partially purified albumin. The binding parameters were used to construct the compartmental model, and the distribution of glycocholate in human adult and fetal blood was compared.

\section{MATERIALS AND METHODS}

Blood $(10 \mathrm{ml})$ from six healthy newborns ( 35 to $40 \mathrm{wk}$ gestation) was collected into lithium-heparin tubes after venepuncture at the placental end of the separated umbilical cord immediately after birth and centrifuged $\left(10 \mathrm{~min} ; 10^{\circ} \mathrm{C} ; 1000 \times \mathrm{g}\right)$. Permission to take blood was obtained from the appropriate Ethics Committee. The plasma was used either immediately (for CM Affi-Gel Blue and gel-exclusion chromatography) or after dialysis against sodium phosphate buffer (125 mM; pH 7.4; buffer 1) (for equilibrium dialysis). Erythrocytes were washed three times with three volumes of phosphate-buffered saline buffer $(10 \mathrm{mM}$; pH 7.4, sodium phosphate buffer plus $154 \mathrm{mM} \mathrm{NaCl}$ ) and then suspended in an equal volume of PBS buffer. The numbers of erythrocytes (about $5 \times 10^{12} /$ liter), leucocytes (about $5 \times 10^{9} /$ liter), and the mean cell volume (about $10^{-13} /$ liter) were measured using a Coulter counter model S. Plasma and erythrocytes were also prepared from blood from four adults (20 to 35 years).

Equilibrium dialysis was performed at $4^{\circ} \mathrm{C}$ using Teflon halfcells (16) separated by a membrane (molecular weight cutoff, 12000 to 14000$)(17)$. Before dialysis, plasma $(1 \mathrm{ml})$ was diluted with $19 \mathrm{ml}$ buffer 1 and portions of this mixture $(1 \mathrm{ml} ; 2 \mathrm{mg}$ protein) were dialysed for $20 \mathrm{hr}$ against $1 \mathrm{ml}$ buffer 1 containing glycocholate. The dissociation constant $\left(\mathrm{K}_{\mathrm{D}}\right)$ and the concentration of binding sites $(\mathrm{N})$ were estimated by fitting rectangular hyperbolae to data for the amount of glycocholate bound (B) and its concentration in free solution $(\mathrm{F})$, assuming that the coefficient of variation of B was constant (4).

To examine the number of binding species, plasma $(1 \mathrm{ml})$ was incubated $\left(4^{\circ} \mathrm{C} ; 30 \mathrm{~min}\right)$ with $1 \mathrm{ml}$ of buffer I containing $\left[{ }^{3} \mathrm{H}\right]$ glycocholate $(20 \mathrm{nM})$ and chromatographed on a Sephadex G-75 column $(57 \times 2.1 \mathrm{~cm})$, equilibrated, and eluted $\left(24 \mathrm{ml} / \mathrm{hr} ; 4^{\circ} \mathrm{C}\right)$ with buffer 1 containing $\left[{ }^{3} \mathrm{H}\right]$ glycocholate $(10 \mathrm{nM})$. The fraction volume was $3.2 \mathrm{ml}$, of which $200 \mu \mathrm{l}$ was assayed for radioactivity, the void volume (Blue Dextran) was $76 \mathrm{ml}$, and the $\mathrm{Na}^{+}$elution volume $200 \mathrm{ml}$.

To determine its ability to bind glycocholate, albumin was separated from the other plasma proteins using CM Affi-Gel Blue (18). The CM Affi-Gel Blue was first washed with isopropanol/ water followed by water, and a column $(8 \mathrm{ml})$ was prepared and eluted with $24 \mathrm{ml}$ potassium phosphate buffer (10 mM, pH 7.25) containing $\mathrm{NaCl}(150 \mathrm{mM})$ (buffer 3). Plasma (1 ml) was then added to the column and eluted with buffer 3 until no further 
$A_{280}$-absorbing material appeared in the eluate. The first three fractions, each of $7 \mathrm{ml}$, were combined (dealbuminated preparation). The column was then eluted with $\mathrm{NaCl}(1.4 \mathrm{M})$, and the three fractions (volume, $7 \mathrm{ml}$ ) containing $\mathrm{A}_{280}$-absorbing material was combined (albumin preparation). Electrophoresis showed that the dealbuminated preparation contained $\alpha_{1}, \alpha_{2}, \beta$, and $\gamma$ globulins but no detectable albumin, and the albumin preparation contained only one protein band which migrated as albumin. Both preparations were diluted with equal volumes of buffer 1 , and the ability of portions ( $1 \mathrm{ml} ; 1.5 \mathrm{mg}$ protein) to bind glycocholate was examined by equilibrium dialysis after initial dialysis $\left(4^{\circ} \mathrm{C} ; 20 \mathrm{hr}\right)$ against buffer 1 .

The interaction of glycocholate with erythrocytes was studied by incubating washed fetal and adult erythrocytes $\left(10^{9}\right.$ cells diluted to $0.2 \mathrm{ml}$ with phosphate-buffered saline buffer) with $0.2 \mathrm{ml}$ buffer 1 containing $\left[{ }^{14} \mathrm{C}\right]$ glycocholate (final concentration, 7.5 to 150 $\mu \mathrm{M})$. After incubation $\left(30 \mathrm{~min} ; 4^{\circ} \mathrm{C}\right)$, the mixtures were centrifuged $\left(2 \mathrm{~min} ; 4^{\circ} \mathrm{C} ; 1000 \times \mathrm{g}\right)$, and radioactivity in the supernatant $(50 \mu \mathrm{l})$ was counted. Inasmuch as the number of cells and their mean cell volumes are known, the volume of buffer and hence the amount of glycocholate in free solution can be calculated. No bile salt was bound by the incubation tubes. The amount of glycocholate associated with the cells was determined by subtracting the unbound glycocholate from the amount originally added. These plots, both for erythrocytes after the initial incubation and after washing, were linear with slopes $S$ and $S_{1}$. If glycocholate were partitioning between the erythrocytes and the suspending medium, both plots should be linear, and $S_{1}$ should equal $S^{2}(12)$. The partition coefficient $\left(\mathrm{K}_{\mathrm{f}}\right)$ of glycocholate between aqueous phase and erythrocytes can then be determined from $S(12)$.

The total amount of glycocholate in $1 \mathrm{ml}$ of blood is the sum of that in free solution (a nmole) and the amounts bound by albumin $\left\{\frac{N a / v}{K_{D}+a / v}\right.$ nmole $\}$, the plasma proteins (b.a.P.), and erythrocytes $\left\{\frac{\mathrm{a}(\mathrm{l}-\mathrm{v})}{\mathrm{K}_{\mathrm{f}} \cdot \mathrm{V}}\right.$ nmole $\}$ where $\mathrm{N}$ is the amount (nmole) of glycocholate bound per mg albumin in $0.45 \mathrm{ml}$ of fetal plasma and $0.55 \mathrm{ml}$ of adult plasma, $\mathrm{V}$ is the volume of plasma in $1 \mathrm{ml}$ of blood, $\mathrm{K}_{\mathrm{D}}$ is the dissociation constant of the albumin-glycocholate complex, $\mathrm{K}_{\mathrm{f}}$ is the partition coefficient, $b$ is the slope of the plot, for nonalbumin protein, of the amount of glycocholate bound against the concentration in free solution, and $P$ is the concentration of nonalbumin protein in plasma. The concentrations of total protein and albumin, respectively, (mean \pm S.D., 5) were $59 \pm 5$ and 36 $\pm 4 \mathrm{mg} / \mathrm{ml}$ in fetal plasma and (mean \pm S.D., 4), $72 \pm 5$ and 40 $\pm 2 \mathrm{mg} / \mathrm{ml}$ in adult plasma. The concentrations of total protein, but not albumin, were significantly different between the two groups $(P<0.05)$. In the six samples of fetal blood, the concentration of cholate conjugates was 0.8 to $5.8 \mathrm{nmoles} / \mathrm{ml}$. The mean concentration ( 2.2 nmoles/liter) was used in the compartmental model. Similar values for random bile salt concentrations are found in adults (2).

Sodium glycocholate (19) $\left[24-{ }^{14} \mathrm{C}\right]$ glycocholate $(20)$, and $\left[\mathrm{G}-{ }^{3} \mathrm{H}\right]$ glycocholate $(21)$ were shown to be $98 \%$ pure by thin-layer chromatography. Protein, $\mathrm{Na}^{+}$, and radioactivity were measured as described (13); cholate conjugates (taurine and glycine) in blood were measured by radioimmunoassay using [ $\left.{ }^{127} \mathrm{I}\right]$ histamine-glycocholate (2). Glycocholate and taurocholate cross-reacted equally with the antiserum, and cholate showed a $10 \%$ cross-reactivity (2). Protein electrophoresis was performed using agarose gels $(115 \times$ $127 \mathrm{~mm}$ ) (22) which were developed (30 min; $100 \mathrm{~V})$ in sodium barbital buffer ( $\mathrm{pH} 8.6 ; 50 \mathrm{mM}+0.35 \mathrm{~g} /$ liter EDTA).

\section{RESULTS}

Equilibrium dialysis showed that glycocholate binding was similar in the six samples of fetal plasma. Saturable binding occurred in five of the six fetal samples examined and in all four of adult plasma with similar values of $\mathrm{K}_{\mathrm{D}}$ (ranges, 0.18 to 0.72 and 0.59 to $0.70 \mathrm{mM}$, respectively). The values of $\mathrm{N}$ (mean \pm S.D.; $\mu$ moles/g protein) were significantly different $(P<0.005$, Student's $t$ test) (fetal plasma, $13.1 \pm 5.0$; adult plasma, $30.9 \pm 7.3$ ). To determine if plasma contains more than one type of binding site, the experimental data (except those from the fetal plasma sample that did not demonstrate saturable binding) were normalised to a common $\mathrm{N}$ and plotted in Scatchard plots, i.e., $\mathrm{B} /(\mathrm{N}$.F.) against $(\mathrm{B} / \mathrm{N})$. Inasmuch as all the plots were linear and nearly coincident, they afforded no evidence for the presence of more than one type of binding site in either fetal or adult plasma.

Chromatography of plasma samples on Sephadex G-75, however, showed two peaks of $\left[{ }^{3} \mathrm{H}\right]$ glycocholate in protein-containing fractions from fetal plasma (Fig. 1). These fractions, eluted between (a) 77 to $80 \mathrm{ml}$ and (b) 93 to $96 \mathrm{ml}$, were separately combined, concentrated about 5 -fold by dialysis against poly(ethylene)glycol (molecular weight, 25000 ), and analysed by electrophoresis. Fractions (a) contained proteins which migrated with the $\alpha_{2}$ and $\gamma$-globulins but not with albumin, whereas fractions (b) contained a prominent albumin band as well as bands corresponding to $\alpha_{1}$ and $\beta$-globulins. Similar results were obtained for plasma from adults. The elution profiles allow $K_{D}$ to be estimated.

$$
\mathrm{K}_{\mathrm{D}}=\frac{(\mathrm{p}-\mathrm{c}) \cdot \mathrm{x}}{\mathrm{c}}
$$

where the concentration of binding sites, ligand, and proteinligand complex are $\mathrm{p}(\mu \mathrm{M})$, x(d.p.s./ml $)$ and $c(d . p . s . / m l)$, respectively. If $K_{D}>x$ so that $p>c$;

$$
\mathrm{K}_{\mathrm{D}}=\mathrm{p} \cdot \frac{\mathrm{x}}{\mathrm{c}}
$$

Assuming each mole of protein in fractions (b) from fetal plasma binds 1 mole of glycocholate, their $\mathrm{K}_{\mathrm{D}}$ (mean \pm S.D., 4) was 0.23 $\pm 0.9 \mathrm{mM}$. Determining the $\mathrm{K}_{\mathrm{D}}$ of binding for the higher molecular weight fractions is difficult because these fractions overlap with the albumin-containing fractions and also because the concentration of binding sites is not known.

Equilibrium dialysis showed that the binding of glycocholate by albumin prepared by chromatography from CM Affi-Gel Blue was saturable (fetal preparation: $\mathrm{K}_{\mathrm{D}}=0.5 \mathrm{mM}, N=11.3 \mu$ moles/ $\mathrm{g}$ protein; and adult preparation: $\mathrm{K}_{\mathrm{D}}=0.42 \mathrm{mM}, N=20.1$ $\mu$ moles/g protein). In contrast, binding by the dealbuminated preparations was not saturable. The experimental data from the adult and fetal preparations were similar and were combined. The plots of the amount of glycocholate bound per mg protein against the concentration of free glycocholate were linear and coincident with a common slope (b) of $0.0062 \mathrm{liter} / \mathrm{g}$, equivalent to 0.62 $\mu$ mole glycocholate/g protein at $100 \mu \mathrm{M}$ free glycocholate. These values of $\mathrm{K}_{\mathrm{D}}, N$, and $\mathrm{b}$ were used to derive the distribution of glycocholate in blood. The binding of glycocholate by the fetal preparations from CM Affi-Gel Blue was also studied by equilibrium gel-exclusion chromatography. Dealbuminated preparation (20 mg) was eluted from Sephadex G-75 and the height of the glycocholate peak eluted between 77 and $80 \mathrm{ml}$ measured. The binding capacity for this species was $0.05 \mathrm{nmole} / \mathrm{g}$ protein at 10 nM glycocholate and was similar to values found by equilibrium dialysis of the dealbuminated preparation. Similar experiments with the albumin preparation gave a $K_{D}$ value for glycocholate binding of $0.8 \mathrm{mM}$.

The association of glycocholate with erythrocytes appeared to depend on partitioning of the bile salt between the cells and the suspending medium; the plots of bound glycocholate against added glycocholate were linear, and the values (mean $\pm S . D ., 4$ ) of $S$ and $S_{1}$ were $0.033 \pm 0.005$ and $0.0016 \pm 0.0005$, respectively (predicted value of $S_{1}, 0.0011$ ). The value of $K_{f}$ (mean \pm S.D., 4) for the association of glycocholate with fetal and adult erythrocytes was $6.0 \pm 0.08$.

The values of $K_{f}, K_{D}$, and $N$ were used to derive the distribution of glycocholate in fetal and adult blood (Table 1). In fetal blood, almost one-half of the glycocholate was in free solution and about one-third was bound to albumin. In the adult, a smaller amount 


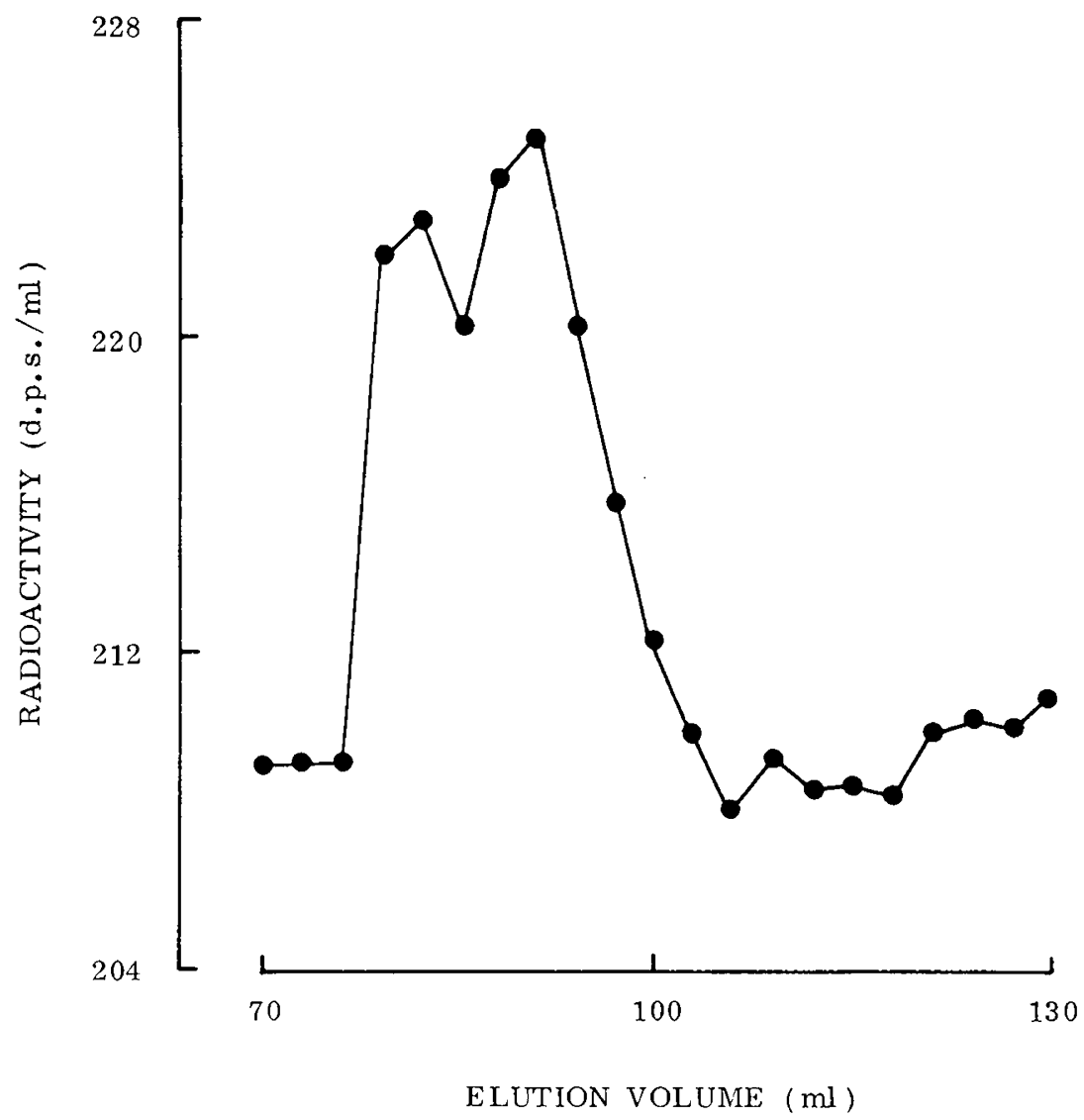

Fig. 1. Equilibrium gel exclusion chromatography: elution of human fetal plasma from Sephadex G-75. Human fetal plasma (1 ml) was incubated with $1 \mathrm{ml}$ buffer $\mathrm{l}$ containing [ ${ }^{3} \mathrm{H}$ ] glycocholate $(20 \mathrm{nM})$ and eluted from Sephadex G-75 using buffer 1 containing [ $\left.{ }^{3} \mathrm{H}\right] \mathrm{glycocholate}(10 \mathrm{nM})$. $\bigcirc$ elution pattern of $\left[{ }^{3} \mathrm{H}\right] \mathrm{glycocholate}$.

Table 1. Derived distribution of glycocholate in blood ${ }^{1}$

\begin{tabular}{lcc} 
& Fetal (nmoles) & Adult (nmoles) \\
\hline Albumin & 0.82 & 1.30 \\
Erythrocytes & 0.21 & 0.09 \\
Nonalbumin protein & 0.15 & 0.13 \\
Free solution & 1.02 & 0.68 \\
\hline
\end{tabular}

'The distribution of glycocholate between plasma proteins, erythrocytes, and the aqueous phase in $1 \mathrm{ml}$ of fetal and adult blood was derived using the compartmental model described in "Materials and Methods." The glycocholate concentration in both fetal and adult blood was 2.2 nmoles $/ \mathrm{ml}$

of bile salt was in free solution although more was bound to plasma albumin. The amount of glycocholate bound by plasma proteins other than albumin was similar in fetal and adult blood although in fetal blood more of the bile salt was associated with erythrocytes.

\section{DISCUSSION}

Determination of the amount of a ligand in free solution in a biological fluid, such as blood, is often difficult if the ligand is associated with erythrocytes and plasma proteins. The compartmental model we have described allows the distribution of glycocholate in fetal and adult blood to be derived and the amount in free solution to be calculated.

Equilibrium dialysis demonstrated that fetal and adult plasma have only one type of saturable binding site for glycocholate. The values of $K_{D}$ for glycocholate binding by fetal plasma were similar to those of adult plasma and also to the values reported for the binding of cholate by human albumin $(0.65 \mathrm{mM}, 11)$ and for the binding of taurocholate to a high affinity site in human plasma (0.5 mM, 3).

Our experiments and those previously described differ in the number of separate bile salt-binding species identified. Burke et al. (3) found secondary, lower affinity sites for taurocholate in human serum but inferred that all the bile salt binding could be accounted for by albumin. Further, Rudman and Kendall (11) did not find glycocholate binding to sites other than those on albumin. Our studies using gel exclusion chromatography show that a binding species, separate from albumin, is present in plasma from adults and fetuses. After it had been separated from albumin, this species demonstrated nonsaturable binding of glycocholate. The estimates of its binding capacity, obtained by gel exclusion chromatography and equilibrium dialysis, were in agreement. The compartmental model indicates that less than $10 \%$ of the bound glycocholate was associated with these lower-affinity binding sites. It is not surprising, therefore, given the errors inherent in equilibrium dialysis (9), that this minority of binding sites was not detected using Scatchard plots.

The compartmental model indicates that in human blood between 5 and $10 \%$ of the glycocholate binds to erythrocytes. The high haematocrit of the fetus means that relatively more glycocholate is associated with its erythrocytes (about $2 \times 10^{4}$ molecules/cell). In the only comparable study, O'Maille et al. (10) showed that in the dog, taurocholate is largely confined to plasma, although at high concentrations (about $150 \mu \mathrm{M}$ ), 25\% of the cholate in blood was taken up by erythrocytes.

The compartmental model indicates that most of the glycocholate in fetal and adult blood is distributed between the aqueous phase and albumin. Fetal blood has more glycocholate in free solution than blood from adults primarily because it has fewer albumin binding sites. There are fewer sites because, firstly, the volume of plasma in $1 \mathrm{ml}$ of blood is less than in adult blood, 
secondly, the concentration of albumin is lower in fetal than in adult plasma, and thirdly, albumin in fetal plasma has a reduced binding capacity for many ligands. This reduction in binding capacity may result from an increase in the concentration of competing ligands such as arachidonic acid, although it is not clear whether albumin from fetal and adult blood have the same protein structure $(1,5,14)$.

\section{REFERENCES AND NOTES}

1. Alayoff, A., Kapitulnik, J., Konija, A., Kaufmann, N. A., and Blondheim, S. H.: Bilirubin binding capacity of albumin isolated from cord-blood serum is less than that from serum of adults. Clin. Chem., 26: 738 (1980).

2. Beckett, G. J., Hunter, W. M.. and Percy-Robb I. W.: Investigations into the choice of immunogen, ligand, antiserum and assay conditions for the radioimmunoassay of conjugated cholic acid. Clin. Chim. Acta, 88: 257 (1978).

3. Burke, C. W., Lewis, B., Panveliwalla, D., and Tabaqchali, S.: The binding of cholic acid and its taurine conjugate to serum proteins. Clin. Chim. Acta, 32: 207 (1971).

4. Cornish-Bowden, A.: Principles of Enzyme Kinetics. pp. 177-181 (Butterworths, London, 1976).

5. Gitzelmann-Cumarasamy, N., Gitzelmann, R., Wilson, K. J., and Kuenzle, C. C.: Fetal and adult albumins are indistinguishable by immunological and physiological criteria. Proc. Natl. Acad. Sci. U. S. A., 76: 2960 (1979).

6. Lester, R., Jackson, B. T., Smallwood, R. A., Watkins, J. B., Klein, P. D., Smith P. M.. and Little, J. M.: Fetal and neonatal hepatic function. II. Birth defects. 12: 307 (1976).

7. Little, J. M., Smallwood, R. A., Lester, R., Piasecki, G. J., and Jackson, B. T.: Bile-salt metabolism in the primate fetus. Gastroenterology, 69: 1315 (1975).

8. Mather, L. E., Long, G. L., and Thomas, J.: The binding of bupivacaine to maternal and fetal plasma proteins. J. Pharm. Pharmacol., 23: 359 (1971).
9. Nimmo, I. A., Atkins, G. L., Strange, R. C., and Percy-Robb, I. W.: An evaluation of ways of using equilibrium dialysis to quantify the binding of ligand to macromolecule. Biochem. J., 165: 107 (1977).

10. O'Maille, E. R. L., Richards, T. G., and Short, A. H.: The Influence of conjugation of cholic acid on its uptake and secretion: hepatic extraction of taurocholate and cholate in the dog. J. Physiol. (Lond.), 189: 337 (1967).

11. Rudman, D., and Kendall, F. E.: Bile acid content of human serum. 11. The binding of cholanic acids by human plasma proteins. J. Clin. Invest.. 36: 538 (1957).

12. Strange, R. C.. Chapman, B. J., Johnston, J. D., Nimmo, I. A.. and Percy-Robb, 1. W.: Partitioning of bile acids into subcellular organelles and the in vivo distribution of bile acids in rat liver. Biochim. Biophys. Acta, 573: 535 (1979).

13. Strange, R. C., Cramb, R., Hayes, J. D., and Percy-Robb, I. W.: Partial purification of two lithocholic acid binding proteins from rat liver $100000 \mathrm{~g}$ supernatants. Biochem. J., 165: 425 (1977).

14. Wallace, S.: Altered plasma albumin in the newborn infant. Br. J. Clin. Pharmacol., 4: 82 (1977).

15. Watkins, J. B., and Perman, J. A.: Bile acid metabolism in infants and children. Clin. Gastroenterol., 6: 201 (1977).

16. Dianorm, Fisons Ltd., Crawley, United Kingdom.

17. Spectrapor, Spectrum Medical Industries, Los Angeles, CA.

18. Bio-Rad Laboratories, Watford, United Kingdom.

19. Weddell Pharmaceuticals Ltd., Clwyd. United Kingdom.

20. Radiochemical Centre, Amersham, United Kingdom.

21. New England Nuclear, Boston, MA.

22. Corning Medical, Essex, United Kingdom.

23. The present address of Richard C. Strange, Central Pathology Laboratory, North Staffordshire Health District, Hartshill Road, Stoke on Trent, Staffordshire, ST4 7PA, England.

24. Requests for reprints should be addressed to: Dr. Richard C. Strange, Central Pathology Laboratory, North Staffordshire Health District, Hartshill Rd., Stoke on Trent. Staffordshire, ST4 7PA. England.

25. Received for publication June 18, 1980.

26. Accepted for publication February 3, 1981. 